\title{
Keanekaragaman Echinodermata di Perairan Pulau Ngele Ngele Kecil, Kabupaten Pulau Morotai
}

\author{
Biodiversity Echinoderm In The Water Of Ngele Ngele Island, Morotai Districts \\ Nurafni, Sandra Hi Muhammad dan Ikbal Sibua \\ Program Studi Ilmu Kelautan, Universitas Pasifik Morotai \\ *E-mail: nurafni1710@gmail.com
}

\begin{abstract}
ABSTRAK
Echinodermata merupakan hewan invertebrata yang memiliki duri pada permukaan kulit, filum ini terbagi atas lima kelas yaitu Bintang laut (Asteroidea), Bintang mengular (Ophiuroidea), Teripang (Holothuroidea) Bulu babi (Echinoidea) dan Lili laut (Crinoidea).. Tujuan penelitian ini adalah mengetahui keanekaragaman Echinodermata diperairan Pulau Ngele-Ngele Kecil. penelitian ini dilakukan pada bulan Oktober 2017 - Januari 2018 dengan menggunakan metode Transek Kuadrat. Penarikan contoh sampling berdasarkan keberadaan Echinodermata dan ditentukan sebanyak 4 stasiun penelitian. Hasil perhitungan nilai kepadatan jenis tertinggi pada jenis Laganum laganum sebesar (14,75 - 14,92 ind/m²) dan yang terendah jenis Ophiarachna affinis, Ophiactis sp, Linckia laevigata dan Protoreaster nodosus sebesar $\left(0,58-0,83 \mathrm{ind} / \mathrm{m}^{2}\right)$ pada masing-masing jenis dalam tiap stasiun. Nilai indeks keanekaragaman jenis tertinggi pada stasiun III sebesar 1,04 dengan kategori sedang dan terendah pada stasiun I diperoleh 0,54. Nilai indeks keseragaman tertinggi pada stasiun II dan III sebesar 0,10 dengan kategori kecil dan yang terendah pada stasiun I sebesar 0,05. Sedangkan nilai indeks dominasi yang diperoleh pada empat stasiun penelitian sebesar 0,02-0,04 dapat dikategorikan dengan kriteria yang rendah.
\end{abstract}

Kata kunci: Keanekaragaman, Echinodermata, Pulau Ngele Ngele

\section{ABSTRACT}

Echinoderms is invertebrate animal with a thorn on the surface of the skin. This phylum is divided into five classes that Starfish (Asteroidea), Infectious Star (Ophiuroidea), Sea Cucumber (Holothuroidea) Sea urchin (Echinoidea) and Sea Lili (Crinoidea). The purposes of this to the diversity of Echinoderms community in Ngele-Ngele Island. This study was conducted in October 2017 - January 2018 using the transect squares method. Sampling is based on the presence of Echinoderms and determined by 4 research stations. The Result showed that calculation of highest density value on Laganum laganum type $\left(14,75-14,92 \mathrm{ind} / \mathrm{m}^{2}\right)$ and the lowest types of Ophiarachna affinis, Ophiactis sp, Linckia laevigata and Protoreaster nodosus of $\left(0.58-0.83 \mathrm{ind} / \mathrm{m}^{2}\right)$ on type in each station. The highest index of species biodiversity at station III is 1.04 with medium and lowest category at station I obtained 0,54. The highest uniformity index value at station II and III was 0,10 with high category and the lowest at station I of 0.05 . While the value of dominance index obtained at four research stations of 0.02 to 0.04 can be categorized by low criteria.

Keywords: Biodiversity, Echinoderms, Ngele Ngele Island 


\section{PENDAHULUAN}

Echinodermata merupakan hewan invertebrata yang memiliki duri pada permukaan kulitnya. Filum Echinodermata terdiri atas 5 kelas, yaitu Asteroidea (bintang laut), Ophiuroidea (bintang mengular), Echinoidea (bulu babi), Holothuroidea (timun laut) dan Crinoidea (lili laut). Umumnya hewan Echinodermata menempati di daerah terumbu karang, pasir dan padang lamun bahkan pada zona tubir, Ciri-ciri hewan ini memiliki tubuh yang kasar karena ditutupi kerangka berduri. Echinodermata memliki nilai ekonomis yang sangat tinggi, beberapa jenis diantaranya seperti teripang dan bulu babi dapat dijadikan sebagai bahan makanan, obat-obatan dan juga diperdagangkan (Katili, 2011). Secara ekologi Echinodermata merupakan salah satu hewan yang sangat penting dalam ekosistem laut dan bermanfaat sebagai salah satu komponen dalam rantai makanan. Dahuri, (2003) hewan ini dapat bersifat pemakan detritus dan predator sehingga peranannya dalam suatu ekosistem dapat merombak sisa-sisa bahan organik yang tidak terpakai oleh spesies lain namun dimanfaatkan oleh beberapa jenis Echinodermata.

Perairan Pulau Ngele-Ngele Kecil berada di Kecamatan Morotai Selatan Barat Kabupaten Pulau Morotai, merupakan salah satu pulau yang kaya akan sumber daya hayati laut salah satunya yaitu komunitas Echinodermata yang cukup berlimpah. Namun pada saat ini terjadi penurunan populasi karena masyarakat setempat sering mengambil biota tersebut untuk dijadikan bahan makanan dan diperdagangkan. Akibat pemanfaatan yang dilakukan oleh masyarakat setempat yang kurang memadai dengan tidak melihat besar kecilnya hewan Echinodermata yang ditangkap akan membawa dampak buruk bagi pertumbuhan organisme laut, sehingga dapat mengakibatkan terjadinya penurunan populasi terhadap Echinodermata. Tujuan penelitian ini adalah untuk mengetahui kenakeragaman echinodermata di Perairan Pulau Ngele Ngele Kecil.

\section{METODE PENELITIAN}

Penelitian ini dilaksanakan pada bulan Oktober 2017 - Januari 2018 di perairan Pulau Ngele-Ngele Kecil, Kabupaten Pulau Morotai.

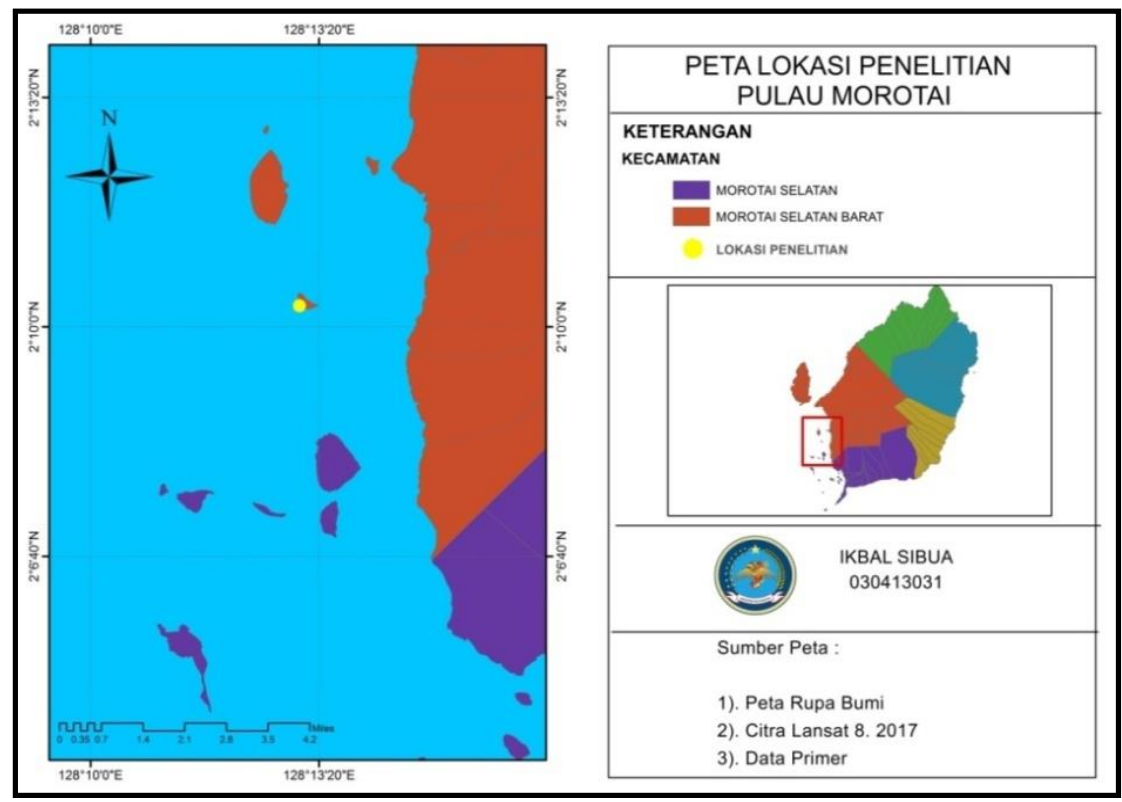

Gambar 1. Peta Lokasi Penelitian 
Alat dan bahan yang digunakan dalam penelitian ini adalah Refraktometer, thermometer, pH (kertas lakmus), GPS, kamera bawa air, Frame (Kuadrat) 1x1 m, kantong plastik, tali plastik (raffia), karet gelang, spidol permanen, pensil dan buku identifikasi.

\subsection{Prosedur Pengambilan Data}

Pengambilan data pada penelitian ini dengan menggunakan transek kuadrat, dilakukan sebanyak empat stasiun dengan tiga kali penempatan kuadrat $1 \times 1 \mathrm{~m}^{2}$ pada setiap transek dalam stasiun penelitian. Jarak setiap stasiun 50 meter dan panjang garis transek adalah 50 meter. Sampel yang diketahui diidentifikasi dengan menggunakan buku identifikasi (Colin dan Arneson, 1995), (Wisnubudi, 2013) dan (Triana et al. 2015). kemudian data dimasukan dalam tabel aplikasi Microsoft Excel 2010. Penarikan garis transek di tarik tegak lurus secara vertikal sepanjang 50 meter pada saat air laut surut atau menjelang surut terendah, mulai dari titik nol dan kuadrat $1 \mathrm{x} 1 \mathrm{~m}^{2}$ diletakan pada setiap jarak yang telah ditentukan dari transek yang dianggap dapat mewakili lokasi yang terdapat Echinodermata. Echinodermata yang terdapat disepanjang transek, di dalam kuadrat diamati komposisi jenis dan dihitung jumlah individu dari masingmasing jenis dan diamati tipe substratnya. Untuk mendapatkan Echinodermata yang membenamkan diri dalam pasir dan memperoleh data yang optimum, maka pencarian Echinodermata dilakukan dengan cara menggali atau menyekop substrat yang berada di dalam kuadrat dan kemudian di hitung jumlah individu dari masing-masing jenis. Untuk lokasi-lokasi yang biotanya jarang, maka dilakukan koleksi bebas dengan cara menyusuri perairan pantai dengan jarak 10 meter disekitar transek kuadrat (Radjab et al. 2014). Selain itu juga dilakukan pengukuran parameter kualitas air diantaranya salinitas, $\mathrm{pH}$, suhu, kedalaman dan pengamatan substrat.

\subsection{Analisis Data}

\subsubsection{Kepadatan Jenis}

Kepadatan jenis adalah jumlah individu per satuan luas. Kepadatan masing-masing jenis pada setiap stasiun dihitung dengan menggunakan rumus (Odum., 1971).

Di mana :

$$
D i=\frac{n i}{A}
$$

Di : Kepadatan jenis

ni : Jumlah total individu jenis

A : Luas daerah yang disampling

\subsubsection{Indeks Keanekaragaman Jenis}

Keanekaragaman jenis dianalisis dengan menggunakan rumus indeks keanekaragaman Shannon-Winner (Krebs., 1985).

$$
H^{\prime}=-\sum_{i=1}^{s} \mathrm{Pi} \log _{2} \mathrm{Pi}
$$


Keterangan:

$\mathrm{H}^{\prime}$ : Indeks keanekaragaman Jenis

$\mathrm{Pi} \quad: \mathrm{ni} / \mathrm{N}$

ni : Jumlah individu spesies ke-i

$\mathrm{N}$ : Jumlah total individu

$\mathrm{S} \quad$ : Jumlah spesies

\subsubsection{Indeks Keseragaman}

Keseragaman dapat dikatakan sebagai keseimbangan, yaitu komposisi individu tiap jenis yang terdapat dalam suatu komunitas. Untuk menghitung keseragaman jenis dengan menggunakan rumus Evennes (Odum., 1993).

$$
E=\frac{H^{\prime}}{H_{\max }}
$$

Keterangan:

E : indeks keseragaman

$\mathrm{H}^{\prime} \quad$ : indeks keanekaragaman

H max : Keanekaragaman spesies maksimum

Indeks keseragaman terdiri dari beberapa kriteria sebagai berikut:

$\mathrm{e}<0,4 \quad$ : Tingkat keseragaman populasi kecil

$0,4>$ e $<0,6$ : Tingkat keseragaman populasi sedang

e $>0,6 \quad$ : Tingkatan keseragaman populasi besar

Indeks Dominasi

Untuk menghitung indeks dominasi digunakan rumus (Odum., 1993)

$$
\mathrm{D}=(\boldsymbol{n i} / \boldsymbol{N})^{2}
$$

Keterangan:

$\mathrm{D}=$ Indeks dominasi

$n i=$ Jumlah individu spesies ke-i

$N=$ jumlah total spesies

Nilai indeks dominasi berkisar antara 0 - 1. Semakin besar nilai indeks dominasi semakin besar kecenderungan salah satu jenis yang mendominasi populasi.

\section{HASIL DAN PEMBAHASAN}

\subsection{Deskripsi Umum Lokasi Penelitian}

Perairan Pulau Ngele-Ngele Kecil terletak di Kecamatan Morotai Selatan Barat Kabupaten Pulau Morotai. Pada bagian timur Pulau ini berbatasan dengan Pulau Ngele-ngele besar, bagian barat berbatasan dengan laut Halmahera, bagian selatan berbatasan dengan Pulau Loleba dan bagian utara berhadapan dengan Desa Usbar Pantai. Perairan ini memiliki pasir 


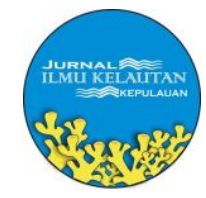

pantai berwarna putih yang halus dan memiliki substrat berpasir, berlumpur, berbatu, karang hidup, karang mati, ditumbuhi lamun, algae dan sedikit mangrove. Letak geografi pada lokasi penelitian yaitu Stasiun I (N 02 $\left.{ }^{0} 10^{\prime} 10.85^{\prime \prime}\right)$ dan (E 128 $\left.8^{\circ} 13^{\prime} 05.61^{\prime \prime}\right)$, Stasiun II (N 02 $\left.10^{\prime} 15.12^{\prime \prime}\right)$ dan (E 128 $\left.{ }^{\circ} 13^{\prime} 03.58^{\prime \prime}\right)$, Stasiun III (N 02 $\left.{ }^{0} 10^{\prime} 17.15^{\prime \prime}\right)$ dan (E 128 13'02.18") dan Stasiun IV (N $\left.02^{0} 10^{\prime} 17.71^{\prime \prime}\right)$ dan (E $\left.128^{0} 13^{\prime} 04.11^{\prime \prime}\right)$.

\subsection{Parameter Lingkungan}

Berdasarkan hasil pengukuran parameter lingkungan meliputi suhu, salinitas, $\mathrm{pH}$, dan kedalaman yang dilakukan pada empat stasiun penelitian dapat dilihat pada tabel dibawah ini:

Tabel 1. Hasil pengukuran parameter lingkungan pada tiap-tiap stasiun.

\begin{tabular}{llcccc}
\multirow{2}{*}{ No } & \multirow{2}{*}{ Parameter } & \multicolumn{4}{c}{ Stasiun } \\
\cline { 3 - 6 } & & I & II & III & IV \\
\hline 1 & Suhu $\left({ }^{\circ} \mathrm{C}\right)$ & 30,3 & 30,0 & 29,3 & 29,7 \\
2 & Salinitas (\%o) & 34,0 & 33,7 & 33,3 & 33,0 \\
3 & Ph & 8,5 & 8,3 & 8,0 & 8,5 \\
4 & Kedalaman $(\mathrm{m})$ & $\leq 1$ & $\leq 1$ & $\leq 1$ & $\leq 1$ \\
\hline
\end{tabular}

Hasil pengukuran suhu pada empat stasiun penelitian diperoleh $29,3-30,3{ }^{\circ} \mathrm{C}$. Hal ini menunjukan bahwa di perairan pulau Ngele-Ngele kecil memiliki suhu masih tergolong normal, kisaran suhu yang diperoleh pada penelitian ini tidak jauh berbeda seperti yang dijelaskan oleh (Aziz, 1998) dalam (Zulfa, 2015) bahwa suhu optimal bagi pertumbuhan biota Echinodermata berkisar antara $25-30{ }^{\circ} \mathrm{C}$. Oleh karena itu suhu perairan yang diperoleh pada empat stasiun penelitian masih dapat ditoleran bagi biota Echinodermata.

Pengukuran salinitas pada empat stasiun penelitian berkisar 33,0 - 34,0 \%o. Kisaran salintas ini masih optimal bagi kehidupan biota laut khususnya Echinodermata. Menurut Aziz, (1996) Echinodermata adalah penghuni sejati dengan batasan toleransi salinitas antara $30-34$ \%. Salinitas adalah salah satu faktor penting yang mempengaruhi pertumbuhan dan perkembangan larva, karena larva Echinodermata lebih sensitif terhadap perubahan salinitas (Aziz, 1994). Hasil pengukuran $\mathrm{pH}$ diperoleh berkisar $8-8,5$. Hal ini menunjukan bahwa di perairan ini memiliki $\mathrm{pH}$ yang masih dapat ditoleran oleh organisme Echinodermata sehingga masih dapat menunjang kehidupannya. Menurut Nybakken, (1992) dalam Zulfa, (2015), pH air laut yang mendukung kehidupan organisme laut antara 7 hingga 8,5 seingga Echinodermata masih bisa bertahan hidup.

Substrat yang diperoleh pada empat stasiun penelitian terdapat empat substrat, yaitu substrat berpasir, berlumpur, berbatu, karang mati dan ditumbuhi lamun. Namun substrat yang mendominasi pada empat stasiun penelitian adalah substrat karang mati dan substrat berpasir. Menurut (Nyebakken, 1988) dalam (Zulfa, 2015) subsrat dasar suatu perairan yang berbeda-beda sangat berpengaruh terhadap komposisi dan distribusi dari organisme benthos. 
JURNAL ILMU KELAUTAN KEPULAUAN, 2 (2) ;74-83, DESEMBER 2019

\subsection{Organisme yang ditemukan pada empat penelitian}

Tabel 2. Jenis yang ditemukan pada empat stasiun penelitian

\begin{tabular}{cllccc}
\hline \multirow{2}{*}{ No } & \multirow{2}{*}{ Jenis Echinodermata } & \multicolumn{5}{c}{ Stasiun } \\
\cline { 2 - 6 } & I & II & III & IV \\
\hline 1 & Protoreaster nodosus & $\sqrt{ }$ & $\sqrt{ }$ & $\sqrt{ }$ & $\sqrt{ }$ \\
2 & Linckia laevigata & - & $\sqrt{ }$ & $\sqrt{ }$ & - \\
3 & Laganum laganum & $\sqrt{ }$ & $\sqrt{ }$ & - & - \\
4 & Ophiomastix janualis & - & $\sqrt{ }$ & $\sqrt{ }$ & $\sqrt{ }$ \\
5 & Ophiarthrum alegans & - & - & $\sqrt{ }$ & $\sqrt{ }$ \\
6 & Ophiolepis superba & - & - & $\sqrt{ }$ & $\sqrt{ }$ \\
7 & Ophiactis sp & - & - & $\sqrt{ }$ & $\sqrt{ }$ \\
8 & Ophiarachna affinis & - & - & $\sqrt{ }$ & $\sqrt{ }$ \\
9 & Holothuria leucaspilota & - & - & $\sqrt{ }$ & $\sqrt{ }$ \\
10 & Holothuria hilla & - & - & $\sqrt{ }$ & $\sqrt{ }$ \\
\hline
\end{tabular}

Ket : $\sqrt{ }:$ Ditemukan

- : Tidak ditemukan

Berdasarkan hasil yang dilakukan pada empat stasiun penelitian di peroleh 10 jenis dari filum Echinodermata yaitu kelas bintang laut (Asteroidea), bintang mengular (Ophiuroidea), teripang (Holothuroidea) dan bulu babi (Echinoidea), sedangkan kelas lili laut (Crinoidea) tidak ditemukan pada empat stasiun penelitian. Hal ini disebabkan karena tempat hidup Lili laut di daerah tubir dan karena pada empat stasiun penelitian ini tidak adanya tubir. Menurut Romadhoni, (2013) hewan kelas Lili laut biasanya hidup pada laut dalam. Selain itu (Yusron, $2010^{1}$ ) juga mengatakan bahwa hewan dari kelas lili laut hidup dan banyak ditemukan di daerah tubir dan di daerah terumbu karang.

Berdasarkan hasil yang diperoleh ditemukan sebanyak 761 individu dalam anggota filum Echinodermata. Hasil menunjukan bahwa terdapat 10 jenis dari 4 kelas lebih jelasnya dapat dilihat pada Lampiran 2. Diperoleh 2 jenis dari kelas bintang laut, 5 jenis dari kelas bintang mengular, 2 jenis dari kelas teripang dan 1 jenis dari kelas bulu babi. Jenis Laganum laganum (dolar pasir) termasuk dalam kelas Bulu Babi merupakan spesies yang memiliki kelimpahan tertinggi yaitu sebanyak 356 individu dan yang paling terendah adalah Linckia laevigata (bintang laut biru) dengan jumlah 18 individu. Sampel di identifikasi dengan menggunakan petunjuk (Colin dan Arneson, 1995), (Wisnubudi, 2013) dan (Triana et al. 2015).

\subsection{Nilai Kepadatan Jenis}

Hasil pengamatan pada empat stasiun penelitian ditemukan 10 jenis dan diperoleh nilai kepadatan dapat dilihat pada gambar berikut ini. 


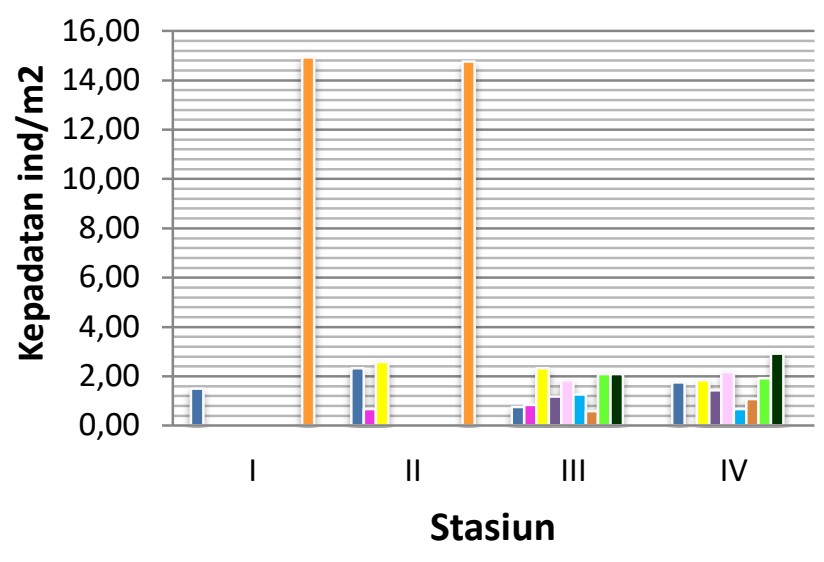

- Protoreaster nodosus

- Linckia laevigata

Ophiomastix janualis

- Ophiarthrum alegans

Ophiolepis superba

- Ophiactis sp

- Ophiarachna Affinis

- Holothuria leucaspilota

- Holothuria Hilla

- Laganum laganum

\section{Gambar 2. Nilai Kepadatan Jenis Echinodermata}

Hasil perhitungan yang diperoleh bahwa kepadatan jenis Echinodermata yang tertinggi dan terendah berdasarkan masing-masing jenis pada empat stasiun penelitian adalah stasiun I diperoleh bahwa jenis Laganum laganum (Dolar pasir) dengan nilai kepadatan tertinggi (14,92 $\mathrm{ind} / \mathrm{m}^{2}$ ) dan Protoreaster nodosus (Bintang laut) memiliki nilai kepadatan terendah (1,50 ind $/ \mathrm{m}^{2}$ ). Tingginya nilai kepadatan jenis Laganum laganum dikarenakan pada stasiun I jenis substrat yang paling mendominasi adalah substrat bepasir dan hewan ini hidup berkelompok sehingga mudah ditemukan dan faktor lingkungan yang diperoleh juga dapat mendukung baik suhu, salinitas maupun $\mathrm{pH}$.

\subsection{Nilai Indeks Keanekaragaman Jenis, Indeks Keseragaman dan indeks Dominansi}

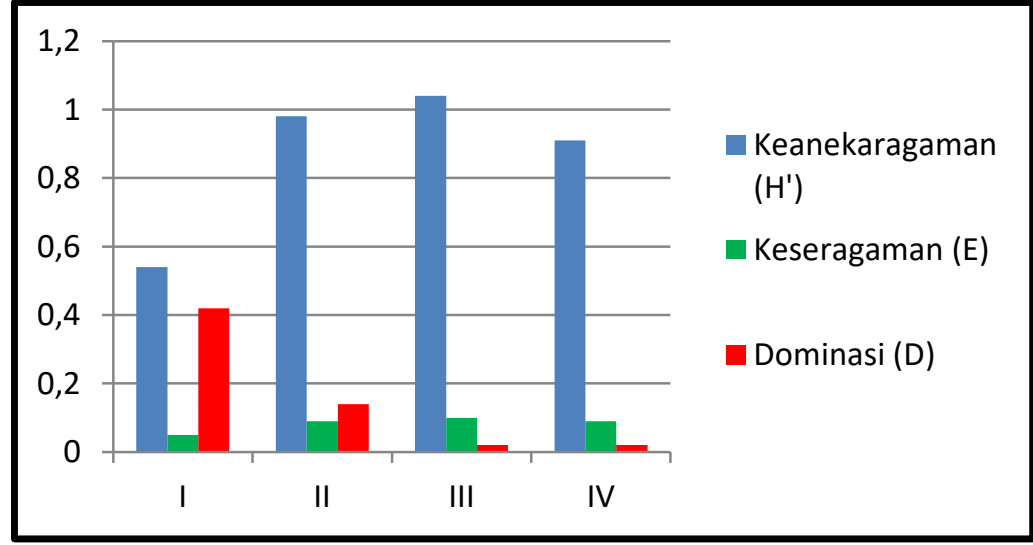

Indeks Keseragaman (E) dan indeks Dominasi (D)

Hasil perhitungan yang diperoleh pada empat stasiun penelitian memiliki nilai keanekaragaman jenis tertinggi terdapat pada stasiun III dengan nilai rata-rata sebesar 1,04 dapat dikategorikan dengan nilai keanekaragaman jenis sedang dan yang terendah pada stasiun I dengan nilai rata-rata 0,54 dapat dikategorikan keanekaragaman jenis rendah diikuti dengan stasiun II dan IV. kriteria nilai keanekaragaman jenis Shannon-Winner yang dikemukakan oleh (Krebs, 1989) dalam (Nova, 2016), jika nilai keanekaragaman jenis yang diperoleh < 1 maka 


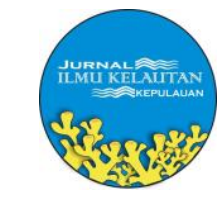

nilai keanekaragaman rendah, 1 - 3 menunjukan keanekaragaman sedang dan jika > 3 menunjukan keanekaragaman jenis yang tinggi.

Tingginya nilai keanekaragaman jenis yang diperoleh pada stasiun III dikarenakan jumlah spesies dan jumlah masing-masing individu yang ditemukan lebih banyak dan hampir merata jumlanya dibandingkan dengan stasiun I, II dan IV. Rendahnya nilai keanekaragaman jenis yang diperoleh pada stasiun I, dikarenakan jumlah yang ditemukan hanya 2 jenis dengan jumlah masing-masing individu yang diperoleh tidak merata. Hal ini dipertegaskan oleh (Barus, 2004) dalam (Hutauruk, 2009) mengatakan suatu komunitas dikatakan mempunyai keanekaragaman jenis yang tinggi apabila terdapat banyak spesies dengan jumlah individu masing-masing spesies yang relatif merata atau hampir sama.

Hasil perhitungan nilai indeks keseragaman pada empat stasiun dengan nilai rata-rata yang diperoleh sebesar 0,05 - 0,10. Nilai terendah pada stasiun I sebesar 0,05 dan nilai indeks keseragaman tertinggi pada stasiun II dan III sebesar 0,10. Nilai indeks keseragaman yang diperoleh pada empat stasiun dapat dikategorikan dengan kriteria yang kecil. Menurut (Odum, 1993) dalam (Saputra, (2017) mengatakan bahwa keseragaman besar berarti kelimpahan setiap spesies reletif seimbang. Nilai indeks dominasi yang diperoleh pada empat stasiun penelitian dengan nilai rata-rata 0,02 - 0,42 dengan nilai indeks dominasi tertinggi diperoleh pada satsiun I sebesar 0,42. Tinggiya nilai indeks dominasi pada stasiun I dikarenakan terdapat satu jenis yang paling mendominasi yaitu jenis Laganum laganum, kemudian diikuti dengan stasiun II sebear 0,14 . Rendahnya nilai indeks dominasi yang diperoleh pada stasiun III dan IV sebesar 0,02-0,04 karena kurangnya jenis yang mendominasi.

\section{Kesimpulan}

Terdapat 10 jenis, 4 kelas dari filum Echinodermata di perairan Pulau Ngele-Ngele Kecil. Jenis kepadatan tertinggi yang ditemukan pada empat stasiun penelitian berasal dari kelas Echinoidea (bulu babi) sebanyak $\left(14,75 \mathrm{ind} / \mathrm{m}^{2}-14,92 \mathrm{ind} / \mathrm{m}^{2}\right)$. Terendah dari kelas Ophiuroidea (bintang mengular) yaitu $\left(0,58 \mathrm{ind} / \mathrm{m}^{2}\right)$ dan kelas Asteroidea (bintang laut) $\left(0,67 \mathrm{ind} / \mathrm{m}^{2}\right)$. Secara umum keanekaragaman jenis Echinodermata termasuk dalam kategori sedang, sedangkan keseragaman dan dominasi termasuk dalam kategori rendah.

Perlu dilakukan penambahan stasiun yang berdekatan dengan perusahan dan pemukiman penduduk sehingga dapat dilihat variasi dari Echinodermata.

\section{Daftar Pustaka}

Aziz A. 1994.Pengaruh Salinitas Terhadap Sebaran Fauna Echinodermata. Jurnal Oseama. Vol 19 Nomor 2. Balai Penelitian dan Pengembangan Biologi Laut, Pusat Penelitian dan Pengembangan Biologi-LIPI, Jakarta.

Aziz A. 1995. Beberapa Catatan Tentang Teripang Bangsa Aspidochirotida. Oseana, 20(4) : 1123. Balai Penelitian dan Pengembangan Biologi Laut, Pusat Penelitian dan Pengembangan Biologi-LIPI, Jakarta. 
Aziz A. 1996. Makanan dan cara makan berbagai bintang laut. Jurnal Oseama. Vol 21 Nomor 3. Balai Penelitian dan Pengembangan Biologi Laut, Pusat Penelitian dan Pengembangan Biologi-LIPI, Jakarta.

Aziz A. 1996. Habiatat dan Zonasi Fauna Ekhinodermata di Ekosistem Terumbu Karang. Oseana, Vol XXI, Nomor 2. Balai Penelitian dan Pengembangan Biologi Laut, Pusat Penelitian dan Pengembangan Biologi-LIPI, Jakarta.

Dahuri R. 2003. Keanekaragaman Hayati Laut. Jakarta: Gramedia Pustaka Utama

Hutauruk L. E. 2009. Studi Keanekaragaman Echinodermata di Kawasan Perairan Pulau Rubiah Nanggroe Aceh. Skripsi. Universitas Sumatra Utara.

Katili S A. 2011. Struktur Komonitas Echinodermata padaZona Intertidal di Gorontalo. Jurnal penelitian dan Pendidikan 8 (1): 52-61.

Nova. A. H. 2016. Keanekaragaman Jenis Ophiuroidea di Zona Intertidal Tanjung Bilik Taman Nasional Baluran. Skripsi. Universitas Jember.

Nurfajriah D. 2014. Struktur komunitas Echinodermata di daerah budidaya karang hias Pulau Panggang, Kepulauan Seribu. Skripsi. Institut Pertanian Bogor.

Odum E P., 1971. Fundamental Of Ecology. Philadelphia London Toronto. W.B. Souders Company.

Odum. 1993. Dasar-dasar ekologi. Diterjemahkan oleh Samingan. Edisi ketiga. Gajah mada University. Yokyakarta.

Pratiwi F. 2011. Inventarisasi Jenis-jenis Holothuroidea (Echinodermata) di Rataan Terumbu Beberapa Pulau Taman Nasional Kepulauan Seribu, Jakarta. Skripsi. Universitas Indonesia.

Rajab W D., Rumahega A S., Soamelo A., Polnaya D., \& Barends W. 2014. Keragaman dan Kepadatan Ekhinodermata di Perairan Teluk Weda, Maluku Utara. Jurnal Ilmu dan Teknologi Kelautan Tropis, 6 (1) 17-30.

Romadhoni F M. 2013. Keanekaragaman Jenis Echinodermata di Pantai Kondang Merak Kecamatan Donomulyo Kabupaten Malang. Sikripsi. Universitas Islam Negeri Maulana Malik Ibraim Malang.

Rumahlatu D., Gafur A dan Sutomo H. 2008. Hubungan Faktor Fisik-Kimia Lingkungan dengan Keanekaragaman Echinodermata pada daerah Pasang Surut Pantai Kairatu. Jurnal (1) 77-85.

Saputra A D. 2001. Struktur Komunitas Teripang (Holothuroidea) di Perairan Pantai Pulau Pramuka dan Pulau Tikus, Kepulauan Seribu, Jakarta. Sikripsi. Institut Pertanian Bogor.

Saputra B H. 2017. Hubungan Kandungan Bahan Organik Sedimen dengan Kelimpahan Asteroidea di Pulau Menjangan Kecil Karimunjawa Jepara. Proposal Penelitian. Universitas Diponegoro Semarang.

Supriadi H., Muzahardan Idris F. 2015. Struktur Komunitas Echinodermata di Terumbu Karang Peraian Laut Teluk Pering Kecamatan Palmatak Kabupaten Kepulauan Anambas. Jurnal: 2-3.

Triana R., Elfidasari D dan Vimono B I. 2015. Identifikasi Echinidermata di Selatan Pulau Tikus, Gugusan Pulau Pari, Kepulauan Seribu, Jakarta. Jurnal 1 (3): 455-459.

Wisnubudi G. 2013. Keanekaragaman dan Kelimpahan Teripang (Holothuroidea) Serta Potensinya di Pulau Kotok Besar, Taman Nasional Laut Kepulauan Seribu (TNKpS). Fakultas Biologi Universitas Nasional Jalan Sawo Mania. 
JURNAL ILMU KELAUTAN KEPULAUAN, 2 (2) ;74-83, DESEMBER 2019

Yusron E. 2006. Biodeversitas Ekhinodermata di Perairan Pantqi Takofi, Pulau Moti - Maluku Utara. SAIN, Vol. 10. No.1, April 2006:41

Yusron E. 2010. Keanekaragaman Jenis Ophiuroidea (bintang mengular) di Perairan Wori, Minahasa Utara, Sulawesi Utara. Jurnal. 14 (1): 75-78.

Yusron E. 2010. Keanekaragaman Jenis Echinodermata di Perairan Likupang, Minahasa Utara, Sulawesui Utara. Bidang Penelitian Sumberdaya Laut, Pusat Oseanografi - LIPI. Vol 15 (2) $85-90$.

Zulfa U. 2015. Keanekaragaman Jenis Asteroidea di Zona Intertidal Pantai Pancur Taman Nasional Alas Purwo. Skripsi. Universitas Jember. 